\title{
Occurrence of Brachyoxylon Hollick et Jeffrey from the Lower Cretaceous of Zhejiang Province, southeastern China
}

\author{
Ning Tian ${ }^{1,2,3^{*}}$, Zhi-Peng Zhu', Yong-Dong Wang ${ }^{2,4^{*}}$ and Si-Cong Wang ${ }^{1}$
}

\begin{abstract}
The Lower Cretaceous Guantou Formation is known as an important horizon for the Cretaceous petrified woods in southern China. Though abundant Cretaceous wood remains have been found in this formation, only one species has been recognized. A new coniferous wood, Brachyoxylon zhejiangense sp. nov. is described from the Lower Cretaceous Guantou Formation in Xinchang of Zhejiang Province, southeastern China. Anatomically, the new species is characterized by obscure annual rings, mixed type of radial pitting, araucarioid cross-field pits and uniseriate xylem rays. The finding of Brachyoxylon zhejiangense sp. nov. represents the first well-defined record of Brachyoxylon in southeastern China, and enriches the diversity of the Early Cretaceous petrified wood in southern China. Additionally, the new finding sheds new light on further understanding the floral composition, especially the forest vegetation type of the southern phytoprovince in the late Early Cretaceous. Diverse compressed leaf fossils of Cheirolepidiaceae have been described from the Guantou Formation in the fossil locality of the present petrified wood. The co-occurrence of Brachyoxylon zhejiangense sp. nov. and those cheirolepidiaceous leaf fossils provide additional evidences to support that Brachyoxylon may be systematically related to the Cheirolepidiaceae.
\end{abstract}

Keywords: Brachyoxylon, Cheirolepidiaceae, Lower Cretaceous, Guantou Formation, Zhejiang Province

\section{Introduction}

Anatomically-preserved petrified woods play significant roles in revealing the floristic composition and evolution of plant kingdom in geological history (Zhang et al. 2006). China is one of the most significant fossil localities for petrified woods with a remarkable high diversity. Until 2006, totally 181 species referred to 106 genera of petrified woods have been reported in China, ranging from Late Paleozoic to Cenozoic in time (Zhang et al. 2006). Xylofloras of China received progressively greater attention over the past decades. An increasing number of Mesozoic petrified woods have been reported from series of horizons in all over China (e.g., Jiang et al. 2008; Wang et al. 2009, 2017; Jiang et al. 2012, 2016; Yang et al. 2013; Feng et al. 2015; Shi et al. 2015; Tian et al. 2015, 2016; Zhang et al. 2015, 2016; Ding et al. 2016;

\footnotetext{
* Correspondence: tianning84@163.com; ydwang@nigpas.ac.cn

${ }^{1}$ College of Palaeontology, Shenyang Normal University, Shenyang 110034 , Liaoning Province, China

${ }^{2}$ State Key Laboratory of Palaeobiology and Stratigraphy, Nanjing Institute of Geology and Palaeontology, CAS, Nanjing 210008, Jiangsu Province, China Full list of author information is available at the end of the article
}

Wan et al. 2016). For the Cretaceous records of petrified woods in China, the spatial-temporal distribution pattern is notably unbalanced. It is noted that 52 species have been described from the Early Cretaceous deposits in China (Yang et al. 2013); whereas, only five species were reported from the Late Cretaceous deposits (Sze 1951; Du 1982; Wang et al. 1996; Terada et al. 2011). Palaeogeographically, most of the Cretaceous petrified woods were described from northern China (especially Northeast China), whereas they are very scarce and limited in southern China (Yang et al. 1990; Duan et al. 2002).

The Lower Cretaceous Guantou Formation is known as an important horizon for the Cretaceous petrified woods in southern China. A large number of petrified woods have been found in this formation; however, only one species has been recognized, i.e., Araucarioxylon xinchangense Duan (Duan et al. 2002). In this paper, a new species of coniferous wood, Brachyoxylon zhejiangense sp. nov. is described based on a fossil wood fragment collected from the Lower Cretaceous Guantou Formation in Xinchang County of Zhejiang Province, 
southeastern China. This new finding enriches the diversity of Early Cretaceous petrified woods in southern China, and sheds new light on further understanding the floral composition, especially the forest vegetation type of the southern phytoprovince in the late Early Cretaceous.

\section{Geological setting, material and methods}

The new fossil material consists of a well-preserved silicified wood fragment found from Lower Cretaceous Guantou Formation in Suqin Village of northwestern Xinchang Basin of Zhejiang Province, southeastern China $\left(29^{\circ} 30^{\prime} 20^{\prime \prime} \mathrm{N}, 120^{\circ} 47^{\prime} 37^{\prime \prime} \mathrm{E}\right.$ ) (Fig. 1). In the Xinchang Basin, the Early Cretaceous strata are well-developed and widely distributed, and can be sub-divided into the Guantou Formation and Chaochuan Formation, ascendingly (Dong et al. 2002). The Guantou Formation mainly crops out in the western edge of the basin (Dong et al. 2002). In the Xinchang Basin, the Guantou Formation is conformably overlain by the Chaochuan Formation, and unconformably overlies on the Upper Jurassic Jiuliping Formation (Fig. 2). Lithologically, the lower part of the
Guantou Formation consists of purple pebbly sandstone and conglomerate, and then ascendingly consists of interbeds of variegated sandstones, siltstones, silty mudstones, and shales. The whole Guantou Formation can be divided into six layers, and the present fossil wood specimen was collected from the layer 4 (Fig. 2). Isotopic dating data of volcanic rock (110-103 Ma) suggest the age of the Guantou Formation to be Early Cretaceous (Albian) (Han et al. 1992; Yu and Xu 1999).

The petrified wood specimen was cut transversely, longitudinally and tangentially into several thin sections. These sections were prepared by standard methods, including cutting, grinding and polishing preparations (Hass and Rowe 1999). Photographs were taken with Scope Image 9.0 (H3D) Software adapted to a Yongxin BM2000 Microscope. The fossil wood specimen and six correlated thin slides described in this paper are housed in the Palaeontological Museum of Liaoning, Shenyang, China, with a registration on number PMOL-B-01476. Fossil wood description follows the standardized terminologies of IAWA Committee (2004) and Philippe and Bamford (2008).

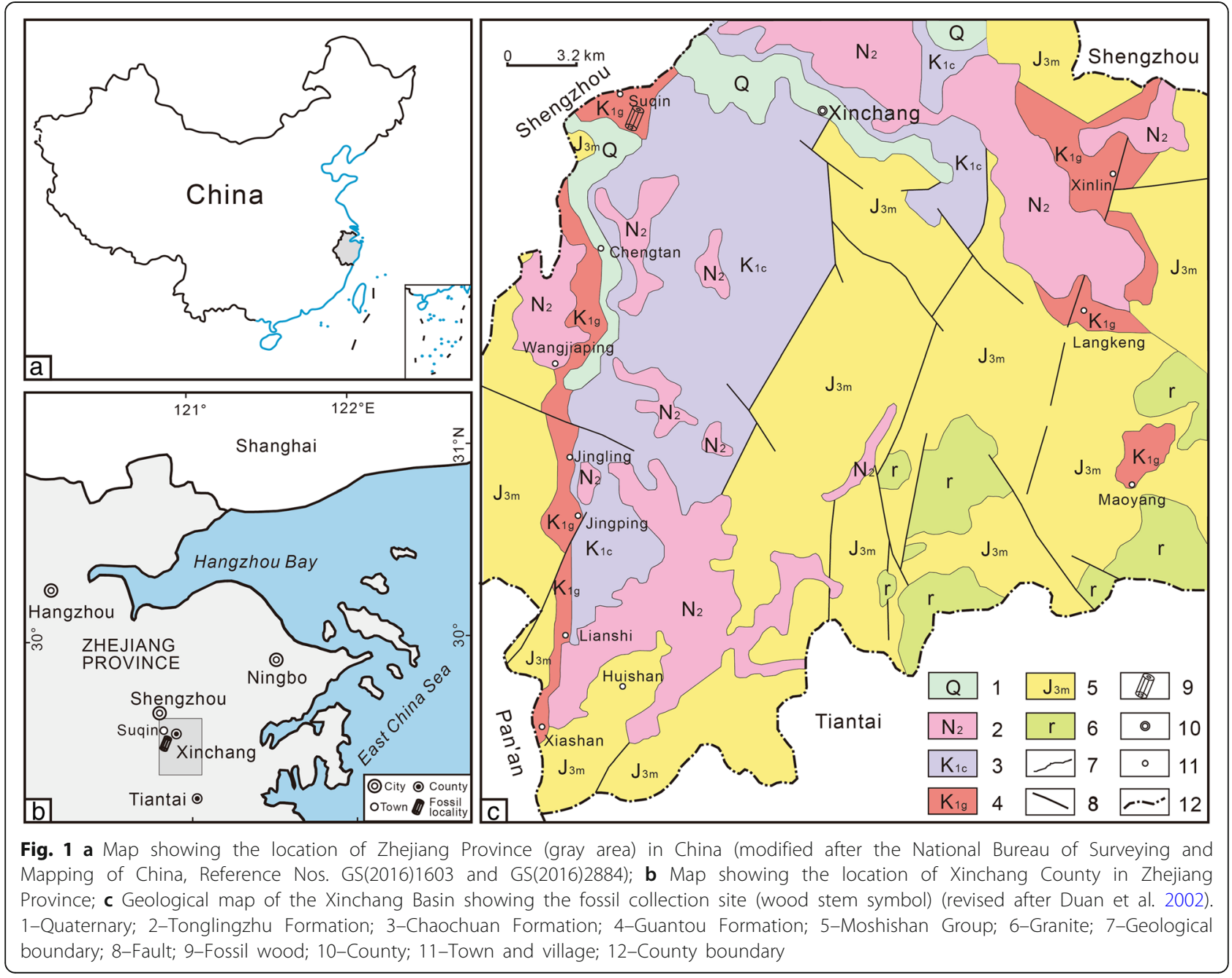




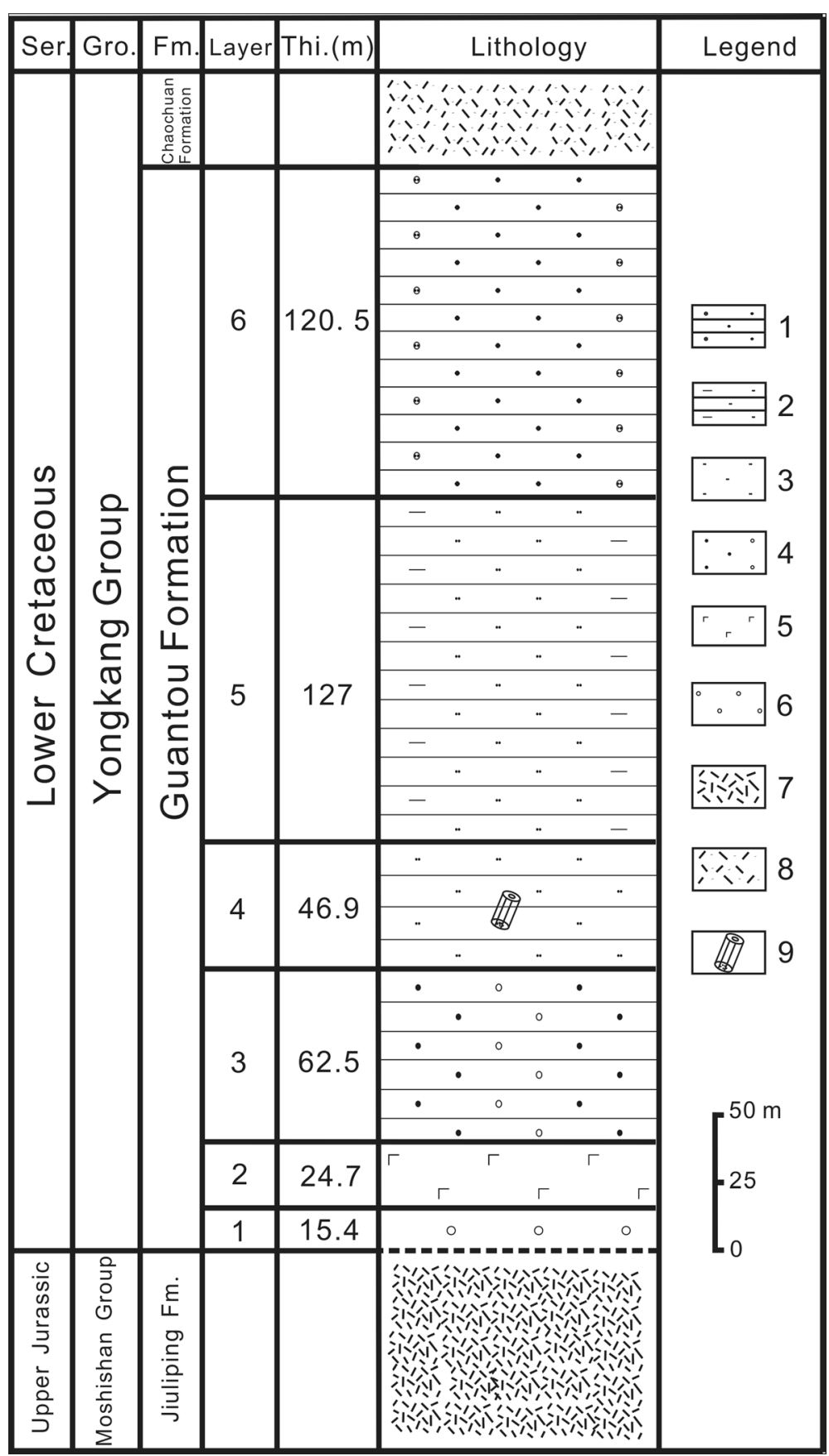

Fig. 2 Stratigraphic column of the Guantou Formation in Xinchang County, Zhejiang Province, SE China (drawn based on lithological description of Duan et al. 2002). 1-Pebbly sandstone; 2-Argillaceous siltstone; 3-Siltstone; 4-Coarse pebbly sandstone; 5-Basalt; 6-Conglomerate; 7-Rhyolite; 8-Tuff; 9-Fossil wood. Ser. = Series; Gro. = Group; Fm. = Formation; Thi. = Thickness

\section{Results}

Class: Coniferopsida

Order: Coniferales

Genus: Brachyoxylon Hollick and Jeffrey 1909

Type species: Brachyoxylon notabile Hollick and Jeffrey 1909
Species: Brachyoxylon zhejiangense sp. nov. Tian, Zhu et Wang

\subsection{Holotype}

PMOL-B-01476 with six sides numbered PMOL-B01476-(a-f). 


\subsection{Type locality}

Xinchang County, Zhejiang Province.

\subsection{Horizon and age}

Guantou Formation, Early Cretaceous.

\subsection{Repository}

The specimen and slides are housed in the Palaeontological Museum of Liaoning, Shenyang, China.

\subsection{Etymology}

The specific epithet zhejiangense refers the fossil locality Zhejiang Province, southeastern China.

\subsection{Specific diagnosis}

Homoxylous secondary xylem with obscure growth rings. Tracheid pitting in radial walls belonging to the mixed type, mostly uniseriate continuous or biseriate alternated, partly uniseriate distant, and rarely biseriate opposite; early wood cross-fields usually with 2-7 cupressoid oculipores, contiguous and alternately arranged in 1-3 rows; horizontal and end walls of ray cells smooth and unpitted; axial parenchyma and resin canals absent. Rays homogeneous, mostly uniseriate and rarely partially biseriate, 1-16 (mostly 2-7) cells high.

\subsection{Description}

The present fossil wood specimen (PMOL-B-01476) is preserved as a fragment of secondary xylem. No anatomical details of the pith and primary xylem are preserved. In the transverse section, the growth rings are weakly defined (Fig. 3a). The transition from the early to late wood is abrupt (Fig. 3a). The late wood zone is very narrow with only 3-5 layers of tracheids. Tracheids of the early wood are large and polygonal and thin-walled, while those of the late wood are rectangular and relatively thick-walled (Fig. 3a).

In the longitudinal radial section, the bordered pits on the tracheid walls belong to the mixed type. Most of them are uniseriate continuous (Fig. $3 \mathrm{~b}-\mathrm{c}$ ) or biseriate alternated (Fig. 3f), partly uniseriate distant (Fig. 3d-e), and very rarely biseriate opposite or sub-opposite (Fig. $3 g$ ). In order to give a clear explanation of the radial pitting type, we counted the percentages of different type of radial pits. We assign each tracheid to a specific type of radial pitting, according to its predominant pitting. Considering that the biseriate opposite pits are rare and only occupy part of a tracheid, as long as biseriate opposite pits are observed in one tracheid, we define the tracheid having biseriate opposite pits. The results show that the uniseriate continuous and biseriate alternated pits are dominant (84.4\% of the total number of tracheids, $n=141$ ), the uniseriate distant ones account for $11.3 \%$, the biseriate opposite and sub-opposite ones account for $4.3 \%$. If only the typical biseriate opposite pits with a square outline is considered, they are with a percentage of $2.1 \%$. Such a result shows that the present fossil wood meets the definition of mixed type of radial pitting defined by Philippe and Bamford (2008). The bordered pits are mostly rounded or slightly flattened, $13-17 \mu \mathrm{m}$ in diameter (Fig. 3b-g). The pit-apertures are oval or rounded, ca. $4.5 \mu \mathrm{m}$ in diameter (Fig. 3b-g). Rays are homogeneous, with both the horizontal and end walls smooth and unpitted (Fig. 3i-k). Cross-field pit arrangement is of the araucarioid type sensu IAWA Committee (2004) (Fig. 4a-c). Each cross-field bears 2-7 bordered pits with circular or oval outline, 23$28 \mu \mathrm{m}$ in diameter, contiguous and arranged in 1-3 rows (Fig. $4 \mathrm{a}-\mathrm{C}$ ). Individual pits are of cupressoid type sensu IAWA Committee (2004). Pit aperture is horizontal or oblique, $6-11 \mu \mathrm{m}$ in diameter (Fig. $4 \mathrm{a}-\mathrm{c}$ ).

In the longitudinal tangential section, rays are homocellular, mostly uniseriate and rarely partially biseriate, 116 (mostly 2-7) cells high (Figs. 4d-e, 5). Generally ca. 35 rays per $\mathrm{mm}^{2}$ are observed. No axial parenchyma and tangential pits were identified in the studied specimen.

\subsection{Taxonomic assignment and comparisons}

For the identification of Mesozoic conifer-like woods, palaeoxylologists have paid much attention to the spacing of pits on tracheid radial walls and cross-field pits. According to Philippe and Bamford (2008), four major types of radial pitting are recognized for Mesozoic conifer-like woods, i.e., araucarian type, abietinean type, mixed type and xenoxylean type. Then, a new type of homoxylous wood radial pitting, the "japonicum type", was recognized based on a revision of the Mesozoic fossil wood from East Asia (Philippe et al. 2014). The current fossil wood is anatomically characterized by having mixed type of radial pitting and araucarioid cross-field pits (oculipores of cupressoid type). Among the morphogenera of Mesozoic conifer-like woods, although the Agathoxylon Hartig and Shimakuroxylon Philippe, Boura, Oh et Pons also have araucarioid cross-field pits, they distinguish from the present studied fossil wood by having araucarian and "japonicum" type of radial tracheid pitting, respectively (Philippe et al. 2004a, 2014; Philippe 2011). Although biseriate opposite and sub-opposite radial pits also occur in the present wood specimen, they are quite rare and account for only 4.3\%. Since Philippe et al. (2014) proposed that a wood specimen which has "japonicum" type of radial tracheid pitting should display at least $10 \%$ of its radial tracheid pit total number being biseriate-opposite, the radial tracheid pitting of the wood studied in this paper does not belong to the "japonicum" type. Only three morphogenera of petrified wood have been defined to have mixed radial tracheid pitting and cross-fields with cupressoid oculipores, i.e., Brachyoxylon Hollick et Jeffrey, Zonaloxylon 

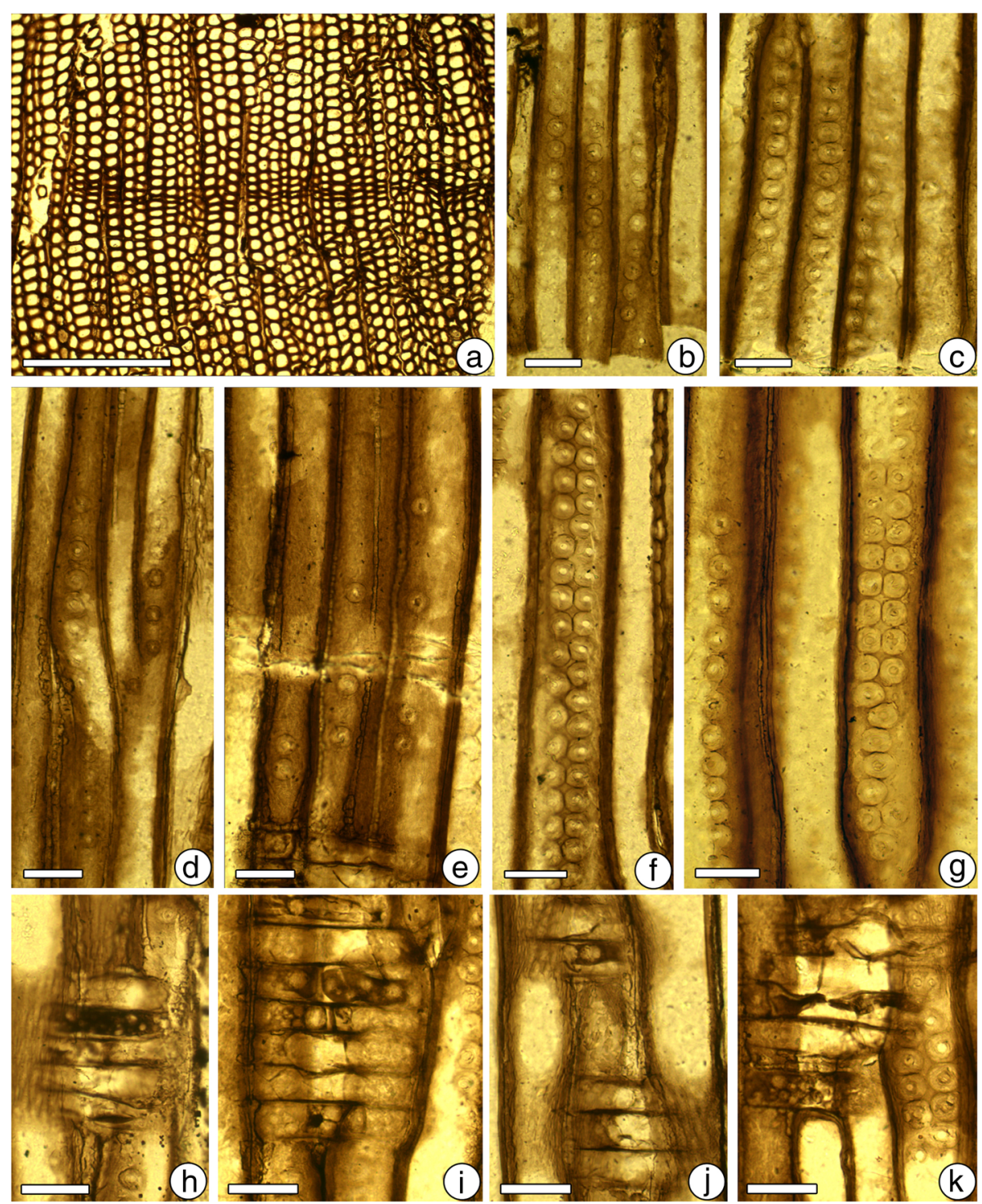

Fig. 3 Brachyoxylon zhejiangense sp. nov. Tian, Zhu et Wang (PMOL-B-01476-a, b) from the Lower Cretaceous Guantou Formation in Xinchang of Zhejiang Province, SE China. a Transverse section, showing the obscure annual ring, scale bar $=0.5 \mathrm{~mm}$; $\mathbf{b}-\mathbf{c}$ Longitudinal section, showing uniseriate, rounded and contiguous bordered pits, scale bar $=0.05 \mathrm{~mm}$; d-e Longitudinal section, showing uniseriate and distant bordered pits, scale $b a r=0.05 \mathrm{~mm} ; \mathbf{f}$ Longitudinal section, showing biseriate alternate bordered pits, scale bar $=0.05 \mathrm{~mm}$; $\mathbf{g}$ Longitudinal section, showing biseriate opposite bordered pits, scale bar $=0.05 \mathrm{~mm}$; $\mathbf{h}-\mathbf{k}$ Longitudinal section, showing the cross-field and smooth horizontal wall of ray cells, scale bar $=0.05 \mathrm{~mm}$

Grauvogel-Stamm et al. and Protocupressinoxylon Eckhold (Philippe and Bamford 2008; Bodnar et al. 2013). However, only Brachyoxylon is characterized by having araucarioid cross-field pits, which are contiguous and/or compressed and alternately arranged oculipores. Therefore, it is reasonable to assign the current fossil wood from China to the genus Brachyoxylon.

Brachyoxylon was originally established for petrified wood from the Upper Cretaceous of the United States (Hollick and Jeffrey 1909). Thereafter, this generic name was employed by many authors for Mesozoic fossil wood remains (Eckhold 1923; Torrey 1923; Kräusel 1949). Though widely used, different authors have different perceptions on how to define Brachyoxylon. Some authors put particular emphasis on the presence of traumatic resiniferous canals (Torrey 1923), while some others focus on the presence of typically araucarian radial pitting (Eckhold 1923). Bamford and Philippe (2001) proposed that Brachyoxylon should be used for tracheidoxyls with mixed tracheid pitting, araucarian cross-fields and with or without traumatic resin canals. During the past century, diverse petrified woods have been referred to this genus. 

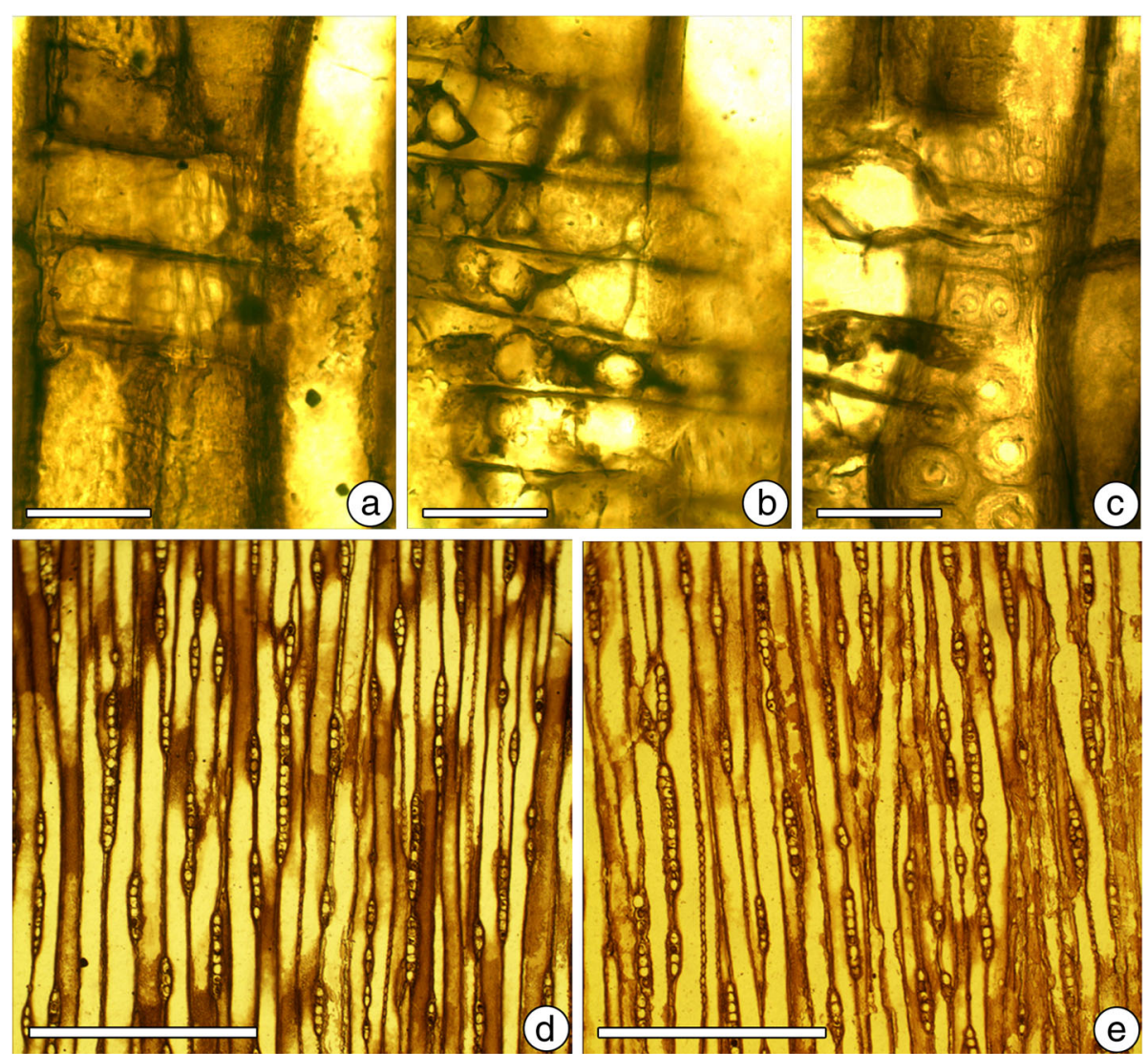

Fig. 4 Brachyoxylon zhejiangense sp. nov. Tian, Zhu et Wang (PMOL-B-01476-b, c) from the Lower Cretaceous Guantou Formation in Xinchang of Zhejiang Province, SE China. a-c Longitudinal section, showing details of the cross-field with 2-7 contiguous, compressed and alternately arranged oculipores, scale bar $=0.1 \mathrm{~mm}$; d-e Tangential section, showing details of xylem ray cells, mostly uniseriate and occasionally partially biseriate, scale bar $=0.5 \mathrm{~mm}$

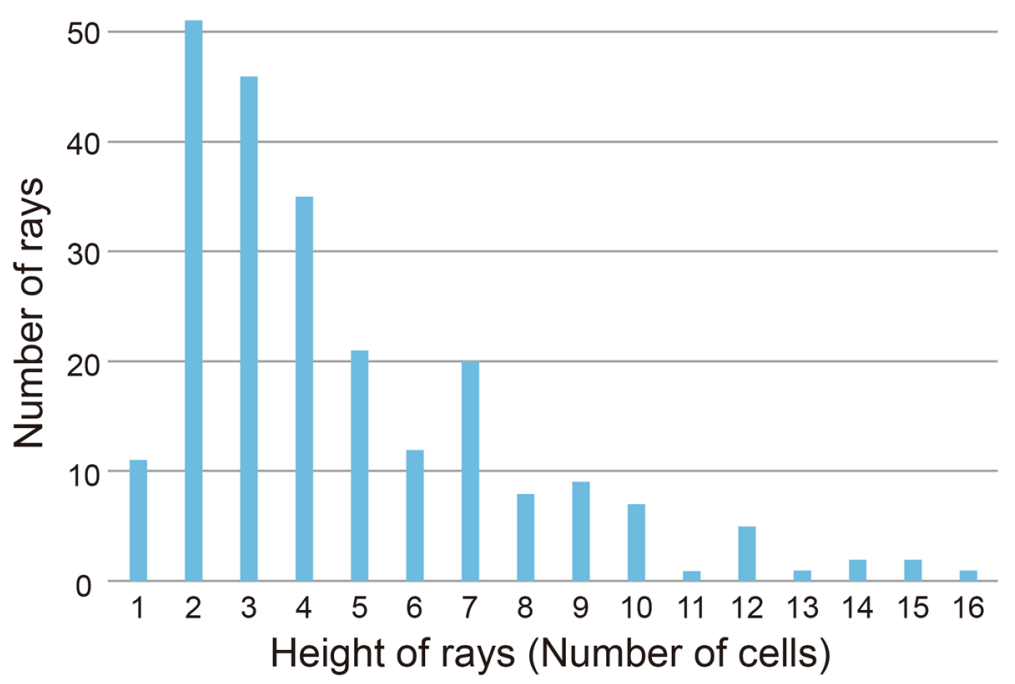

Fig. 5 The height frequency distribution of ray cells in a tangential section of Brachyoxylon zhejiangense sp. nov. 
Even recently, a new species Brachyoxylon baqueroensis Vera et Césari was described from the Lower Cretaceous in Patagonia (Vera and Césari 2015). A comprehensive and detailed comparison between 17 species of Brachyoxylon was given in Bodnar et al. (2013). It is noted that among those listed Brachyoxylon species, five species (i.e., $B$. brachyphylloides (Torrey) Kräusel, B. japonicum (Shimakura) Kräusel, B. saurinii Boureau et Serra, B. boureauii Serra, and B. orientale (Serra) Philippe et al.) were later reassigned to Shimakuroxylon by Philippe et al. (2014). An updated comparative table of Brachyoxylon species is given (Table 1). Since there is no previously published species of this genus comparable with the present fossil wood from China, a new species Brachyoxylon zhejiangense sp. nov. is proposed.

It is noted that, including the type species Brachyoxylon notabile Hollick et Jeffrey, many Brachyoxylon species (e.g., B. trautii (Barale) Philippe, B. liebermanii Philippe, $B$. avramii Iamandei et Iamandei, $B$. dobrogiacum Iamandei et Iamandei, B. semibiseriatum (Pant et Singh) Kurzawe et Merlotti, and $B$. serrae Philippe et al.) are characterized by having tangential tracheid pitting and/or traumatic resin ducts (Table 1). Nevertheless, neither tangential tracheid pitting nor traumatic resin ducts are observed in Brachyoxylon zhejiangense sp. nov. Being different from the new species from China, Brachyoxylon currumilii from the Lower-Middle Jurassic of Argentina bears scanty and diffuse axial parenchyma (Bodnar et al. 2013). Another Argentina species, Brachyoxylon baqueroensis differs from the new species by having distinct annual rings, triseriate radial pits, and a higher number of cross-field pits (Vera and Césari 2015). Generally, Brachyoxylon zhejiangense sp. nov. seems to be more comparable to B. woodworthianum Torrey (mid-Cretaceous,

Table 1 Comparative table of species of the genus Brachyoxylon (modified after Bodnar et al. 2013)

\begin{tabular}{|c|c|c|c|c|c|c|c|c|c|c|}
\hline Species & Age & Distribution & $\begin{array}{l}\text { False } \\
\text { GR }\end{array}$ & $\begin{array}{l}\text { Resin } \\
\text { ducts }\end{array}$ & $\begin{array}{l}\mathrm{Tg} \\
\mathrm{TP}\end{array}$ & $\mathrm{Rd}$ TP & $\begin{array}{l}\mathrm{Ax} \\
\mathrm{Pa}\end{array}$ & $\mathrm{Cr}$ & $\begin{array}{l}\text { Rays } \\
\text { (height) }\end{array}$ & CFP \\
\hline $\begin{array}{l}\text { Brachyoxylon zhejiangense } \\
\text { sp. nov. Tian, Zhu et Wang }\end{array}$ & Early Cretaceous & China & A & A & $A$ & $\begin{array}{l}\text { mixed 1-2 } \\
\text { seriate }\end{array}$ & A & A & $\begin{array}{l}\text { mostly } 1 \text { seriate } \\
(1-16 \text { cells })\end{array}$ & 2-7 cupressoid \\
\hline $\begin{array}{l}\text { B. notabile Hollick and } \\
\text { Jeffrey } 1909\end{array}$ & Late Cretaceous & USA & A & $\mathrm{T}$ & $\mathbf{P}$ & $\begin{array}{l}\text { mixed } 1-2 \\
\text { seriate }\end{array}$ & A & $\mathbf{P}$ & $\begin{array}{l}1 \text { seriate } \\
\text { (1-8 cells })\end{array}$ & 5-11 cupressoid \\
\hline $\begin{array}{l}\text { B. woodworthianum } \\
\text { Torrey } 1923\end{array}$ & Early Cretaceous & USA & A & $\mathrm{T}$ & A & mixed & A & A & $\begin{array}{l}1-2 \text { seriate } \\
(2-20) \text { cells }\end{array}$ & cupressoid \\
\hline $\begin{array}{l}\text { B. saurinii Boureau and } \\
\text { Serra } 1961\end{array}$ & Jurassic (?) & Cambodia & A & $\mathrm{T}$ & A & $\begin{array}{l}\text { mixed } 1-2 \\
\text { seriate }\end{array}$ & A & A & $\begin{array}{l}1 \text { seriate } \\
\text { (1-31 cells) }\end{array}$ & 2-12 cupressoid \\
\hline $\begin{array}{l}\text { B. lagonense } \\
\text { (Laudouéneix 1973) } \\
\text { Dupéron-Laudouéneix } 1991\end{array}$ & Cretaceous & Chad & A & $\mathbf{T}$ & A & $\begin{array}{l}\text { mixed 2-3 } \\
\text { seriate }\end{array}$ & A & A & 1 seriate (low) & cupressoid \\
\hline $\begin{array}{l}\text { B. trautii (Barale 1981) } \\
\text { Philippe } 1995\end{array}$ & Middle Jurassic & France & $\mathbf{P}$ & A & $\mathbf{P}$ & $\begin{array}{l}\text { mixed 1-2 } \\
\text { seriate }\end{array}$ & A & A & 1 seriate (low) & 4-9 cupressoid \\
\hline B. liebermanii Philippe 1995 & Jurassic & France & $\mathbf{P}$ & A & $\mathbf{P}$ & $\begin{array}{l}\text { mixed } 1 \\
\text { seriate }\end{array}$ & A & A & 1 seriate (low) & $\begin{array}{l}5-12 \text { cupressoid } \\
\text { to podocarpoid }\end{array}$ \\
\hline $\begin{array}{l}\text { B. eboracense } \\
\text { (Holden 1913) } \\
\text { Philippe } 2002\end{array}$ & Jurassic & England & A & A & A & $\begin{array}{l}\text { mixed 1-2 } \\
\text { seriate }\end{array}$ & A & A & 1 seriate, (low) & $\begin{array}{l}\text { numerous } \\
\text { cupressoid }\end{array}$ \\
\hline $\begin{array}{l}\text { Brachyoxylon sp. } \\
\text { Philippe et al. 2004b }\end{array}$ & Late Jurassic & Thailand & $\mathbf{P}$ & A & $\mathbf{P}$ & $\begin{array}{l}\text { mixed 1-2 } \\
\text { seriate }\end{array}$ & A & A & 1 seriate, (low) & $\begin{array}{l}\text { up to } 12 \\
\text { cupressoid }\end{array}$ \\
\hline $\begin{array}{l}\text { B. avramii lamandei } \\
\text { and lamandei } 2005\end{array}$ & Early Cretaceous & Romania & A & $\mathrm{T}$ & $\mathrm{R}$ & $\begin{array}{l}\text { mixed, 1-2 } \\
\text { seriate }\end{array}$ & A & $A$ & $\begin{array}{l}1 \text { seriate } \\
(1-21 \text { cells })\end{array}$ & 1-8 cupressoid \\
\hline $\begin{array}{l}\text { B. dobrogiacum } \\
\text { lamandei and lamandei } 2005\end{array}$ & Early Cretaceous & Romania & A & A & $\mathbf{P}$ & $\begin{array}{l}\text { mixed 1-3 } \\
\text { seriate }\end{array}$ & $\mathbf{P}$ & $\mathrm{P}$ & $\begin{array}{l}1 \text { seriate } \\
(1-10 \text { cells })\end{array}$ & 1-6 cupressoid \\
\hline $\begin{array}{l}\text { B. semibiseriatum } \\
\text { (Pant and Singh 1987) } \\
\text { Kurzawe and Merlotti } 2010\end{array}$ & Permian & Brazil & $A$ & $\mathbf{P}$ & $\mathbf{P}$ & $\begin{array}{l}\text { mixed } 1-5 \\
\text { seriate }\end{array}$ & A & A & $\begin{array}{l}1 \text { seriate } \\
\text { ( } 1-38 \text { cells })\end{array}$ & 4-16 cupressoid \\
\hline B. serrae Philippe et al. 2011 & Early Cretaceous & Thailand & A & $\mathrm{T}$ & $\mathbf{P}$ & $\begin{array}{l}\text { mixed 1-2 } \\
\text { seriate }\end{array}$ & A & A & $\begin{array}{l}1 \text { seriate } \\
(1-15 \text { cells })\end{array}$ & 5-16 cupressoid \\
\hline $\begin{array}{l}\text { B. currumilii Bodnar et al. } \\
2013\end{array}$ & $\begin{array}{l}\text { Early-Middle } \\
\text { Jurassic }\end{array}$ & Argentina & A & A & $\mathrm{R}$ & $\begin{array}{l}\text { mixed 1-2 } \\
\text { seriate }\end{array}$ & $\mathbf{R}$ & A & $\begin{array}{l}1 \text { seriate } \\
(1-10 \text { cells })\end{array}$ & 4-11 cupressoid \\
\hline $\begin{array}{l}\text { B. baqueroensis Vera and } \\
\text { Césari } 2015\end{array}$ & Late Cretaceous & Argentina & A & A & A & $\begin{array}{l}\text { mixed } 1-3 \\
\text { seriate }\end{array}$ & A & A & $\begin{array}{l}1 \text { seriate } \\
\text { (1-9 cells) }\end{array}$ & 8-26 cupressoid \\
\hline
\end{tabular}

Note: Anatomical characters that differ from those of the new species Brachyoxylon zhejiangense sp. nov. are bolded GR Growth rings, Tg TP Tangential tracheid pitting, Rd TP Radial tracheid pitting, Ax Pa Axial parenchyma, Cr Crassulae, CFP Cross-field pits, $P$ Present, A Absent, $T$ Traumatic, $R$ Rare 
North America) in ray height, obscure annual rings, and the absence of tangential tracheid pitting and parenchyma; however, original description of $B$. woodworthianum shows that it has traumatic resin canals and abietan pitting in traumatic ray cells (Torrey 1923).

\section{Discussion}

As a fossil wood morphogenus, the systematic affinity of Brachyoxylon is still undetermined. It has been linked to various coniferous families, such as Araucariaceae (Hollick and Jeffrey 1909), and Cupressaceae (Seward 1919). However, Brachyoxylon has been more frequently related to the distinct family Cheirolepidiaceae (e.g., Alvin et al. 1981; Alvin 1982; Machhour and Pons 1992; Limarino et al. 2012). The finding of Brachyoxylon woods in association with conifer leaves and Classopollis-bearing cones (Zhou 1983) suggests that at least some Brachyoxylon woods may be representatives of the Cheirolepidiaceae. In fact, the type species B. notabile Hollick et Jeffrey was related to Brachyphyllum macrocarpum Newberry 1896, a possible Cheirolepidiaceae (Alvin 1982). It is of interest that compressed leaf fossils of possible Cheirolepidiaceae, e.g., Pseudofrenelopsis parceramosa (Fontaine) Watson, Pagiophyllum delicatum Cao, P. obtosior Cao, and $P$. xinchangense Cao, have also been described from the Lower Cretaceous Guantou Formation in the same fossil locality (Suqin Village of Xinchang County, Zhejiang Province) with Brachyoxylon zhejiangense sp. nov. (Cao 1989, 1991). Additionally, Pseudofrenelopsis papillosa Chow et Tsao and P. parceramosa have also been found from the Guantou Formation in adjacent Jingling Village of Xinchang County (Ren et al. 2008). Generally, the co-occurrence of Brachyoxylon wood and leaf fossils of Cheirolepidiaceae in the Lower Cretaceous Guantou Formation further implies that the fossil wood genus Brachyoxylon may be systematically referable to the conifer family Cheirolepidiaceae.

Fossils of Brachyoxylon have been widely documented from both the boreal and Gondwana regions range from the Permian to the Late Cretaceous (Philippe et al. 2004a; Bodnar et al. 2013). Palaeogeographically, Brachyoxylon is much more common in boreal areas (e.g., the United States, Tunisia, Japan, Cambodia, Thailand, France and Romania) than in Gondwana region (Philippe et al. 2004a; Bodnar et al. 2013). Though abundant and diverse Mesozoic wood remains have been described, fossil records of Brachyoxylon are very scarce in China. Vozenin-Serra and Pons (1990) assigned a wood sample from the Lower Cretaceous in Lhunzhub of Tibet, southwestern China to Protopodocarpoxylon orientale Serra. However, due to its araucarioid cross-field pits, Philippe et al. (2004a) proposed it as a new combination Brachyoxylon orientale (Serra) Philippe et al. Then recently, this specimen is reassigned to Shimakuroxylon japonicum
(Shimakura) Philippe et al. for having radial pitting of “japonicum-type" (Philippe et al. 2014). Additionally, Brachyoxylon sp. has been reported from the Lower Cretaceous in Lhasa of Tibet (Vozenin-Serra and Pons 1990; Zhang et al. 2006). Generally, the new finding of Brachyoxylon zhejiangense sp. nov. enriches the diversity of the Early Cretaceous petrified wood in southern China, and contributes to further understanding the floral composition, especially the forest composition of the southern phytoprovince in the late Early Cretaceous.

\section{Conclusions}

A new coniferous wood, Brachyoxylon zhejiangense sp. nov. was is described from the Lower Cretaceous Guantou Formation of Zhejiang Province, southeastern China, which represents the first record of Brachyoxylon wood in southeastern China. The new finding provides new clues for understanding the palaeogeographical distribution of this genus, as well as the forest composition of the Early Cretaceous flora in southeastern China. Additionally, the co-occurrence of Brachyoxylon wood and cheirolepidiaceous leaf fossils in the Guantou Formation further implies that Brachyoxylon may be systematically referable to the Cheirolepidiaceae.

\begin{abstract}
Acknowledgements
We thank Dr. Zi-Kun Jiang (Beijing, China) for her helpful discussion. Special appreciations are due to Prof. Mihai E. Popa (Bucharest, Romania) and Marc Philippe (Lyon, France) for their detailed comments and valuable suggestions that improved this paper. This study was jointly supported by the Strategic Priority Research Program (B) of the Chinese Academy of Sciences (Grant Nos. XDB18000000 and XDB26010302), the State Key Program of Research and Development of Ministry of Science and Technology, China (Grant No. 2016YFC0600406), the National Natural Science Foundation of China (Grant Nos. 41302004, 41688103, and 41790454), the State Key Laboratory of Palaeobiology and Stratigraphy (NIGPAS, CAS) (Grant Nos. 133113 and 173124), and the Special Fund of Liaoning Provincial Universities' Fundamental Scientific Research Project (Grant No. LQN201718).
\end{abstract}

Authors' contributions

NT and YW designed and performed research; NT, YW, ZZ and SW analyzed the data. NT and ZZ made the figures; NT, YW, ZZ and SW wrote the paper. All authors read and approved the final manuscript.

Competing interests

The authors declare that they have no competing interests.

\section{Publisher's Note}

Springer Nature remains neutral with regard to jurisdictional claims in published maps and institutional affiliations.

\section{Author details}

${ }^{1}$ College of Palaeontology, Shenyang Normal University, Shenyang 110034, Liaoning Province, China. ${ }^{2}$ State Key Laboratory of Palaeobiology and Stratigraphy, Nanjing Institute of Geology and Palaeontology, CAS, Nanjing 210008, Jiangsu Province, China. ${ }^{3}$ Key Laboratory of Evolution of Past Life in Northeast Asia, Ministry of Land and Resources, Shenyang 110034, Liaoning Province, China. ${ }^{4}$ Center for Excellence in Life and Palaeoenvironment, Chinese Academy of Sciences, Nanjing, Jiangsu Province 210008, China. 
Received: 6 July 2017 Accepted: 13 October 2017 Published online: 20 September 2018

\section{References}

Alvin, K.L. 1982. Cheirolepidiaceae: Biology, structure and paleoecology. Review of Palaeobotany and Palynology 37 (1): 71-98.

Alvin, K.L., C.J. Fraser, and R.A. Spicer. 1981. Anatomy and palaeoecology of Pseudofrenelopsis and associated conifers in the English Wealden. Palaeontology 24 (4): 759-778.

Bamford, M.K., and M. Philippe. 2001. Jurassic-early cretaceous Gondwanan homoxylous woods: A nomenclatural revision of the genera with taxonomic notes. Review of Palaeobotany and Palynology 113 (4): 287-297.

Barale, G. 1981. La paléoflore jurassique du Jura français: étude systématique, aspects stratigraphiques et paléoecologiques. Documents des Laboratoires de Géologie de Lyon 81: 1-467 (in French).

Bodnar, J., I. Escapa, N.R. Cúneo, and S. Gnaedinger. 2013. First record of conifer wood from the Cañadón Asfalto formation (early-middle Jurassic), Chubut Province, Argentina. Ameghiniana 50 (2): 227-239.

Boureau, E., and C. Serra. 1961. Sur les structures normales et traumatiques d'un bois mésozoïque du Cambodge, le Brachyoxylon saurinii n. sp. Revue Générale de Botanique 68: 373-393 (in French).

Cao, Zheng-Yao. 1989. Some Lower Cretaceous gymnospermae from Zhejiang with study on their cuticles. Acta Palaeontologica Sinica 28 (4): 435-440 (in Chinese with English abstract).

Cao, Zheng-Yao. 1991. On four new species of Pagiophyllum from Guantou Formation, Xinchang, Zhejiang. Acta Palaeontologica Sinica 30 (5): 593-600 (in Chinese with English abstract).

Committee, I.A.W.A. 2004. IAWA list of microscopic features for softwood identification. IAWA Journal 25 (1): 1-70.

Ding, Qiu-Hong, Ning Tian, Yong-Dong Wang, Zi-Kun Jiang, Shu-Wang Chen, Dong Wang, Wu Zhang, Shao-Lin Zheng, Ao-Wei Xie, Guo-Qiang Zhang, and Zhong-Jian Liu. 2016. Fossil coniferous wood from the Early Cretaceous Jehol Biota in western Liaoning, NE China: New material and palaeoclimate implications. Cretaceous Research 61: 57-70.

Dong, Chuan-Wan, Guo-Qiang Zhu, Zhong-Hui Yu, and Shan-Kun Gao. 2002. Study on the petrology of strata bearing petrified wood and the palaeoecology in Xinchang, Zhejiang Province. Journal of Zhejiang University (Science Edition) 29 (2): 202-208 (in Chinese with English abstract).

Du, Nai-Zheng. 1982. Two fossil woods from Heilongjiang Sheng of China. Acta Botanica Sinica 24 (4): 383-389 (in Chinese with English abstract).

Duan, Shu-Ying, Chuan-Wan Dong, Jiang Pan, and Guo-Qiang Zhu. 2002. Study on the fossil woods found in Xinchang, Zhejiang Province, China. Chinese Bulletin of Botany 19 (1): 78-86 (in Chinese with English abstract).

Dupéron-Laudouéneix, M. 1991. Importance of fossil woods (conifers and angiosperms) discovered in continental Mesozoic sediments of northern equatorial Africa. Journal of African Earth Sciences 12: 391-396.

Eckhold, W. 1923. Die Hoftüpfel bei rezenten und fossilen Coniferen. Jahrbuch der preußischen geologischen Landesanstalt zu Berlin 42: 472-505 (in German).

Feng, Zhuo, Hai-Bo Wei, Chun-Ling Wang, Yu-Xuan Chen, Jia-Jia Shen, and JiYuan Yang. 2015. Wood decay of Xenoxylon yunnanensis Feng sp. nov. from the middle Jurassic of Yunnan Province, China. Palaeogeography, Palaeoclimatology, Palaeoecology 433: 60-70.

Han, Wen-Bin, Wen-Yu Zhang, Wen-Ming Huang, Cheng-An Ma, and Yu-Rong Wang. 1992. The isotopic ages of volcanic rocks of Moshishan and Yongkang groups in Wuyi of Zhejiang Province. In Collected Works of Volcanic Geology and Mineral Resources in the Southeastern Coast of China (1), ed. Zhi-Gang Lu and Kui-Yuan Tao, 72-81. Beijing: Geological Publishing House (in Chinese).

Hass, H., and N.P. Rowe. 1999. Thin section and wafering. In Fossil plants and spores: Modern techniques, ed. T.P. Jones and N.P. Rowe, 76-81. London: Geological Society of London.

Holden, R. 1913. Contributions to the anatomy of Mesozoic conifers. 1 Jurassic coniferous woods from Yorkshire. Annals of Botany 27: 533-545.

Hollick, A., and E.C. Jeffrey. 1909. Studies of coniferous cretaceous remains from Kreischerville, New York. Memoirs of the New York Botanical Garden 3: 1-137.

lamandei, E., and S. lamandei. 2005. Early cretaceous protopinaceous fossil wood from south Dobrogea, Romania. Acta Palaeontologica Romaniae 5: 231-247.

Jiang, Hong-En, D.K. Ferguson, Cheng-Sen Li, and Ye-Ming Cheng. 2008. Fossil coniferous wood from the middle Jurassic of Liaoning Province, China. Review of Palaeobotany and Palynology 150 (1): 37-47.
Jiang, Zi-Kun, Yong-Dong Wang, M. Philippe, Wu Zhang, Ning Tian, and Shao-Lin Zheng. 2016. A Jurassic wood providing insights into the earliest step in Ginkgo wood evolution. Scientific Reports 6: 38191.

Jiang, Zi-Kun, Yong-Dong Wang, Shao-Lin Zheng, Wu Zhang, and Ning Tian. 2012. Occurrence of Sciadopitys-like fossil wood (Coniferales) in the Jurassic of western Liaoning and its evolutionary implications. Chinese Science Bulletin 57 (6): 569-572.

Kräusel, R. 1949. Die fossilen Koniferen-Hölzer (Unter Ausschluß von Araucarioxylon Kraus) II. Teil. Kritische Untersuchungen zur Diagnostik lebender und fossiler Koniferen-Hölzer. Palaeontographica Abteilung B 89 (46): 83-203 (in German).

Kurzawe, F., and S. Merlotti. 2010. O complexo Dadoxylon-Araucarioxylon, Carbonífero e Permiano do Gondwana: estudo taxonômico do gênero Araucarioxylon. Pesquisas em Geociências 37: 41-50 (in Portuguese).

Laudoueneix, M. 1973. Sur deux bois homoxylés de la région de Lagon (Tchad). Toulouse: Compte rendu du 96ème Congrès national des Sociétés savantes de Paris et des départements, Sciences 5: 107-131 (in French).

Limarino, C.O., M.G. Passalia, M. Llorens, E.I. Vera, V.S. Perez Loinaze, and S.N. Césari. 2012. Depositional environments and vegetation of Aptian sequences affected by volcanism in Patagonia. Palaeogeography, Palaeoclimatology, Palaeoecology 323-325: 22-41.

Machhour, L., and D. Pons. 1992. Bois de coniférales dans I'Albien du synclinal du Beausset (Var, SE France): Signification paléogéographique et paléoclimatique. Geobios 25 (2): 181-193 (in French).

Pant, D.D., and V.K. Singh. 1987. Xylotomy of some woods from Raniganj formation (Permian), Raniganj Coalfield, India. Palaeontographica Abteilung B $203(1-3): 1-82$.

Philippe, M. 1995. Bois fossiles du Jurassique de Franche-Comté (nord-est de la France): systématique et biogéographie. Palaeontographica Abteilung B 236: 45-103 (in French).

Philippe, M. 2002. Reappraisal of five fossil coniferous wood genera proposed by early American wood anatomists. IAWA Journal 23 (3): 319-326.

Philippe, M. 2011. How many species of Araucarioxylon? Comptes Rendus Palevol 10 (2-3): 201-208.

Philippe, M., and M.K. Bamford. 2008. A key to morphogenera used for Mesozoic conifer-like woods. Review of Palaeobotany and Palynology 148 (2): 184-207.

Philippe, M., M.K. Bamford, S. McLoughlin, L.S.R. Alves, H. Falcon-Lang, S. Gnaedinger, G. Ottone, M. Pole, A. Rajanikanth, R.E. Shoemaker, T. Teresa, and A.B. Zamuner. 2004a. Biogeographic analysis of Jurassic-early cretaceous wood assemblages from Gondwana. Review of Palaeobotany and Palynology 129: 141-173.

Philippe, M., A. Boura, C. Oh, and D. Pons. 2014. Shimakuroxylon a new homoxylous Mesozoic wood genus from Asia, with palaeogeographical and palaeoecological implications. Review of Palaeobotany and Palynology 204: 18-26.

Philippe, M., V. Suteethorn, and É. Buffetaut. 2011. Révision de Brachyoxylon rotnaense Mathiesen, description de B. serrae $\mathrm{n}$. sp. et conséquences pour la stratigraphie du Crétacé inférieur d'Asie du Sud-Est. Geodiversitas 33: 25-32 (in French).

Philippe, M. V. Suteethorn, P. Lutat, E. Buffetaut, L. Cavin, G. Cuny, and G. Barale. 2004b. Stratigraphical and palaeobiogeographical significance of fossil wood from the Mesozoic Khorat group of Thailand. Journal of Thermophysics and Heat Transfer 141 (3): 319-328.

Ren, Wen-Xiu, Bai-Nian Sun, Xiang-Chuan Li, Jing-Yu Wu, Liang Xiao, and YongDong Wang. 2008. Microstructures of two species of Cheirolepidiaceae from cretaceous in Zhejiang, China and its paleoenvironmental significance. Acta Geologica Sinica 82 (5): 577-583 (in Chinese with English abstract).

Seward, A.C. 1919. Fossil Plants. Vol. 4, 217-286. Cambridge: Cambridge University Press.

Shi, Xiao, Jian-Xin Yu, J. Broutin, and D. Pons. 2015. Junggaropitys, a new gymnosperm stem from the middle-late Triassic of Junggar Basin, Northwest China, and its palaeoecological and palaeoclimatic implications. Review of Palaeobotany and Palynology 223: 10-20.

Sze, H.C. 1951. Petrified woods from northern Manchuria. Science Record 4 (4): 443-457.

Terada, K., H. Nishida, and G. Sun. 2011. Fossil woods from the upper cretaceous to Paleocene of Heilongjang (Amur) River area of China and Russia. Global Geology 14 (3): 192-203.

Tian, Ning, Yong-Dong Wang, M. Philippe, Li-Qin Li, Xiao-Ping Xie, and Zi-Kun Jiang. 2016. New record of fossil wood Xenoxylon from the late Triassic in the Sichuan Basin, southern China and its paleoclimatic implications. Palaeogeography, Palaeoclimatology, Palaeoecology 464: 65-75. 
Tian, Ning, Ao-Wei Xie, Yong-Dong Wang, Zi-Kun Jiang, Li-Qin Li, Ya-Lei Yin, ZhiPeng Zhu, and Jia-Jia Wang. 2015. New records of Jurassic petrified wood in Jianchang of western Liaoning, China and their palaeoclimate implications. Science China Earth Sciences 58 (12): 2154-2164.

Torrey, R.E. 1923. The comparative anatomy and phylogeny of the Coniferales, part. 3: Mesozoic and tertiary coniferous woods. Memoirs of Boston Society of. Natural History 6: 39-106.

Vera, E.I., and S.N. Césari. 2015. New species of conifer wood from the Baqueró Group (Early Cretaceous) of Patagonia. Ameghiniana 52 (4): 468-471.

Vozenin-Serra, C., and D. Pons. 1990. Intérêts phylogénétique et paléoécologique des structures ligneuses homoxylées découvertes dans le Crétacé inférieur du Tibet méridional. Palaeontographica Abteilung B 216: 107-127 (in French).

Wan, Ming-Li, Wei-Ming Zhou, Peng Tang, Lu-Jun Liu, and Jun Wang. 2016. Xenoxylon junggarensis sp. nov., a new gymnospermous fossil wood from the Norian (Triassic) Huangshanjie Formation in northwestern China, and its palaeoclimatic implications. Palaeogeography, Palaeodlimatology, Palaeoecology 441 (4): 679-687.

Wang, Ru-Feng, Yu-Fei Wang, and Yong-Zhe Chen. 1996. Cupressinoxylon Jiayinense, a new species of the Late Cretaceous from the Heilongjiang Province, China. IAWA Journal 17 (3): 319-326.

Wang, Yong-Dong, Ning Tian, Zi-Kun Jiang, Xiao-Ju Yang, and Qiu-Hong Ding. 2017. Recent advances in Mesozoic fossil wood studies in China: Diversity variations and palaeoclimate implications. Earth Sciences Frontiers 24 (1): 5264 (in Chinese with English abstract).

Wang, Yong-Dong, Xiao-Ju Yang, Wu Zhang, Shao-Lin Zheng, and Ning Tian. 2009. Biodiversity and palaeoclimatic implications of fossil wood from the non-marine Jurassic of China. Episodes 32 (1): 13-20.

Yang, Jia-Ju, Guo-Fan Qi, and Rui-Hu Xu. 1990. Studies on fossil woods excavated from the Dabie Mountains. Scientia Silvae Sinicae 26 (4): 379-383 (in Chinese with English abstract).

Yang, Xiao-Ju, Yong-Dong Wang, and Wu Zhang. 2013. Occurrences of Early Cretaceous fossil woods in China: Implications for paleoclimates. Palaeogeography, Palaeoclimatology, Palaeoecology 385: 213-220.

Yu, Yun-Wen, and Bu-Tai Xu. 1999. Stratigraphical sequence and geochronology of the upper Mesozoic volcano-sedimentary rock series in Zhejiang. Journal of Stratigraphy 23 (2): 136-145 (in Chinese with English abstract).

Zhang, Feng, Xu-Feng Hu, Xun-Oian Wang, Can Xiong, and Yi-De Hu. 2015. The discovery of middle Jurassic petrified wood from Qijiang in Chongqing and its scientific significances. Acta Palaeontologica Sinica 54 (2): 261-266 (in Chinese with English abstract)

Zhang, Feng, Feng-Ping Wang, Wei Li, Hai-Ping Zhang, Xu-Feng Hu, Xun-Qian Wang, and Hai-Dong Yu. 2016. Discovery of late Jurassic petrified wood from Penglaizhen formation of Qijiang, southern Chongqing and its scientific significances. Acta Palaeontologica Sinica 55 (2): 207-213 (in Chinese with English abstract).

Zhang, Wu, Yong Li, Shao-Lin Zheng, Nan Li, Yong-Dong Wang, Xiao-Ju Yang, Jia-Ju Yang, Tie-Mei Yi, and Xiao-Ping Fu. 2006. Fossil woods of China. Beijing: China Forest Publishing House (in Chinese).

Zhou, Zhi-Yan. 1983. A heterophyllous cheirolepidiaceous conifer from the Cretaceous of East China. Palaeontology 26 (4): 789-811.

\section{Submit your manuscript to a SpringerOpen ${ }^{\circ}$ journal and benefit from:}

- Convenient online submission

- Rigorous peer review

- Open access: articles freely available online

- High visibility within the field

- Retaining the copyright to your article

Submit your next manuscript at $\boldsymbol{\nabla}$ springeropen.com 